\title{
Poultry and Wild Bird Interactions: An Assessment of Risk Factors in Kogi State, Nigeria
}

\author{
Negedu Onogu Ameji ${ }^{1 *}$, Assam Assam ${ }^{2}$, Paul Ayuba $\mathrm{Abdu}^{3}$, Lawal Sa'idu ${ }^{4}$ and Murtala Isa-Ochepa ${ }^{5}$ \\ ${ }^{I}$ Department of Veterinary Medicine, Surgery and Radiology, University of Jos, Nigeria \\ ${ }^{2}$ Department of Animal Sciences, Cross River State University of Technology, Obubra Campus, Nigeria \\ ${ }^{3}$ Department of Veterinary Medicine, Ahmadu Bello University, Zaria, Nigeria \\ ${ }^{4}$ Veterinary Teaching Hospital, Ahmadu Bello University, Zaria, Nigeria \\ ${ }^{5}$ Ministry of Agriculture, Kogi State, Nigeria \\ *Corresponding author's Email: amejivet@gmail.com, ORCID: 0000000210522799
}

Received: 20 Apr. 2021

Accepted: 03 June 2021

\begin{abstract}
Wild birds are involved in the spread of avian pathogens such as avian influenza and Newcastle disease viruses over long distances. This study aimed to identify conditions that can promote poultry-wild bird interactions and consequently enhance risk of introduction, spread, and maintenance of avian pathogens within poultry population in Kogi State, Nigeria. Data were collected through structured questionnaires administered to poultry farmers and poultry sellers in farms, live bird markets (LBMs), and households and cross checked by observers using a checklist. Of the 108 respondents, $86.4 \%$ affirmed that wild birds scavenge for food on their farms, households, and LBMs, $73.1 \%$ kept poultry on free range and $67.9 \%$ indicated the presence of trees, where wild birds settle, on their farms, households, or LBMs. However, 53.3\% were near major rivers/wetlands while $9.3 \%$ had fish ponds near their farms or households. Nonetheless, $94.7 \%$ of respondents dispose dead poultry and litter in refuse dumps and $77.2 \%$ of the respondents had farms along transit routes. Spearman's rho showed strong positive correlations between poultry and wild bird interaction with high rates of scavenging by wild birds on farms and around households, presence of major rivers, free-range poultry and transit routes for live bird trade, spillage of poultry feed and presence of tress for roosting of wild birds on the farms. The frequencies of risk factors for poultry and wild bird interactions were high in Olamaboro, Ajaokuta, Dekina, Ofu, Ankpa, Lokoja, Okene, and Ogori-Mangogo local government areas of the State. There is a need to train poultry farmers and sellers of Kogi State on biosecurity practices to reduce the level of poultry and wild bird interactions to prevent the risk of the introduction and spread of avian pathogens by wild birds.
\end{abstract}

Keywords: Interactions, Live bird markets, Pathogens, Poultry, Risk factors, Wild birds

\section{INTRODUCTION}

Wild birds are known to be reservoirs of some important avian pathogens and may disperse them to poultry flocks which can affect negatively poultry production due to huge economic losses (FAO, 2007). Factors that increase the chance of direct or indirect interactions between wild birds and poultry can increase the risk of introduction and transmission of avian pathogens from the wild birds to poultry or vice versa (Elmberg et al., 2017). In Kogi State, Nigeria, poultry production falls under sector 4 of the FAO classification of the poultry production systems which corresponds to the village or backyard poultry with inadequate housing and poor biosecurity that may increase the likelihood of poultry and wild birds interactions leading to exchange of pathogens (Adene and Oguntade, 2006; Pagani et al., 2008). The interactive exchange of pathogens may lead to maintenance and continuous spread of pathogens and the resultant increase in the virulence of pathogens that were hitherto quiescent in the wild (Lee et al., 2017).

Surveillance, biosecurity and other control measures such as vaccination, treatment, and culling may successfully control infection of contagious avian diseases in domestic poultry but not in wild birds because of the difficulty in their applications in a constantly mobile system (Dhama et al., 2008; Halifa, 2008). Biosecurity is a day to day routine of management practices with two main objectives which are bio-exclusion and bio-containment 
through isolation, traffic control, and sanitation of the farm (Dhama et al., 2008; USAID, 2009). Hence, biosecurity can only be effectively applied in a closed system or where the environment can be modified which is often difficult with wild birds and poultry on free range to a large extent (Dhama et al., 2008).

The mobility of wild birds and the challenge of tracking different populations make it of great importance to identify and focus on the risk factors that favor their presence, interactions, and transmission of pathogens between wild birds and domestic poultry (Gilbert et al., 2008). The use of responses from respondents or expert opinions to risk questions, termed the modified Delphi method, to determine incidence and prevalence risk has been a valid tool in predictive risk assessment over a long period (Kilpatrick et al., 2006; Singh et al., 2018).

This study collected data through structured questionnaires and observations to establish the presence of risk factors for direct and indirect contacts between wild birds and poultry which may lead to introduction, maintenance and spread of avian infections as reported elsewhere (Vieira et al., 2009; Singh et al., 2018). The study provides baseline data on poultry and wild bird interactions which will assist in designing a way for reducing these interactions. The risk factors identified in the study will also be used in developing preventive measures required against the future introduction and spread of avian pathogens from wild birds to poultry in Kogi State, Nigeria.

\section{MATERIALS AND METHODS}

\section{Study area}

The study area was Kogi State of Nigeria which lies between Latitude $6^{\circ} 44^{\prime}-7^{\circ} 36^{\prime} \mathrm{N}$ and Longitude $7^{\circ} 49^{\prime}$ $8^{\circ} 27^{\prime}$ E situated at a height of about $789 \mathrm{~km}$ above sea level and covering a land area of $29,833 \mathrm{Km}^{2}$. The State is bordered by nine States with the Federal Capital Territory and Niger State on the north, Benue and Nasarawa States on the east, Ekiti and Kwara States on the west, Edo, Anambra and Enugu States on the south.

The vegetation of Kogi State is guinea savannah on the north and a belt of rain forest on the southern fringe with rivers Niger and Benue passing through the State, which later converged at a point to form a confluence. The annual rainfall ranges from $1100-1250 \mathrm{~mm}$ starting from April to October (Kogi, 2009; Ameji et al., 2015).

The State has a total of 21 Local Government Areas (LGAs) with a human population of 2,099,046 and major economic activities of the people being crop farming, fishing, and trading (Kogi, 2009). The population of poultry in the State is estimated to be 3,685,211 with $91.5 \%$ being rural or backyard poultry and the rest being commercial poultry (Adene and Oguntade, 2006; Ameji et al., 2015).

\section{Sample size and sampling method}

Using Snedecor and Cochran (1989) method, the alpha level was set at 5\% and 50\% prevalence was used to estimate the population proportion in order to calculate the sample size. The sample size calculated was 103 but it was increased to 108 respondents comprising of 36 rural poultry farmers, 36 backyard commercial poultry farmers, and 36 poultry sellers which were selected randomly from a list of 140 registered poultry farms and live bird markets (LBMs) that was obtained from the Avian Influenza Control Program (AICP) Desk office in Kogi State.

Backyard poultry, according to Pagani et al. (2008), refers to the farming of improved/exotic breeds of poultry (i.e. small-scale farming of improved poultry breed in the backyard). Rural poultry is also called village poultry and refers to the indigenous or local breed of poultry (Adene and Oguntade, 2006).

\section{Administration of questionnaire}

A semi-structured questionnaire was designed, pretested on 12 respondents, and modified to cover 38 variables and risk questions. During the administration of questionnaire, respondents gave their consent with the help of the National Animal Disease Information System (NADIS) agents in each of the LGAs.

The respondents were from 12 LGAs grouped into 3 agro zones designated as zones $\mathrm{A}, \mathrm{B}$, and $\mathrm{C}$ based on similarities in culture, contiguity, geographical features, and agricultural activities. Each zone has 4 LGAs, zones A and $\mathrm{B}$ constituting areas of high backyard commercial poultry activities including the State capital situated within the central and western flanks of Kogi State which included Adavi, Ajaokuta, Ijumu, Kabba/Bunu, Lokoja, Mopamuro, Ogori-Mangogo, and Okene LGAs. Zone C constitutes areas with mostly rural poultry and few backyard commercial poultry farms situated within the eastern flank of Kogi State which included Ankpa, Dekina, Ofu, and Olamaboro LGAs. Zones A and B had similar cultural and farming systems and were grouped as $\mathrm{A}+\mathrm{B}$ which was compared with zone $\mathrm{C}$.

The questionnaire was administered by interview to 3 backyard poultry farmers, 3 live bird marketers, and 3 rural poultry farmers in each of the 12 LGAs to obtain data about the type of poultry being kept, the level of 
biosecurity and husbandry practices, spillage of feed during feeding of poultry, disposal of litter or dead poultry in refuse dump, presence of water body or fish pond near the farm or household, presence of wetland or river in the area as well as wild birds seen around farms or households and their local names. The answers given by the respondents were cross-checked by researchers' observations using a checklist.

\section{Assessment of wild bird and poultry interactions and associated risk factors}

The assessment of poultry and wild bird interactions was done using a combination of information obtained from the administered questionnaires and observation checklist.

The observation checklist for the assessment of possible interactions was based on factors that directly or indirectly influence contact between poultry and wild birds, including the absence of adequate housing or poultry on free range, spillage of feed during feeding or broadcasting of feed for free range poultry, presence of wild birds and poultry together at common water and feed points, presence of tall grasses or trees for roosting, presence of water body or fish pond near the farms or households, poultry supply/market chain as well as presence of major river or wetlands in the area.

Wild birds seen during the survey were photographed and identified using an identification guide (Borrow and Demey, 2002). Features that may serve as risk factors for poultry and wild bird interactions were also photographed and along with the other recorded observations were used to draw a map of the risk pathways of likely introduction and spread of avian pathogens in the State.

\section{Statistical analysis}

The data obtained from the questionnaire were checked for completeness, entered in Microsoft Excel 2010 after validation, and the errors in data entry were corrected and analyzed based on LGAs by descriptive and analytical statistics using SPSS version 17.0 (SPSS Inc., Chicago, IL, USA).

Risk factors were categorized as direct and indirect, based on whether the factor causes direct or indirect interaction. LGAs were categorized into three groups (i.e., low, medium, or high) based on the occurrence rate of risk factors. Spearman correlation test was used to assess the relationship between identified factors with poultry and wild bird interactions within LGAs. Also, univariate analysis was used to assess the odds of occurrence of risk factors for poultry - wild bird interactions in Zone $\mathrm{C}$ against Zones A + B. For all analyses, a p-value of $<0.05$ was taken as significant.

\section{RESULTS}

\section{Assessment of poultry and wild bird interactions}

A total of nine factors that may serve as possible risks for interactions between poultry and wild birds were considered. The risk factors identified through questionnaire that may increase the likelihood of poultry and wild bird interactions were disposal of litter or dead poultry in refuse dump $(94.7 \%)$, scavenging of wild birds around poultry farms and households $(86.4 \%)$, location of farms along transit routes for live bird trade (77.2\%), keeping poultry on free range $(73.1 \%)$ and presence of roosting sites for wild birds around farms or households (67.9\%) (Tables 1 and 2).

Nevertheless, farms, households, and LBMs near rivers or wetlands as well as those sharing borders with high poultry producing or highly pathogenic avian influenza (HPAI) infected States had medium risk with $55.6 \%$ of respondents in such areas. Also, feed spillage and drying of feed ingredients in the open space had a medium risk with $53.5 \%$ of the respondents reporting such practices (Tables 1 and 2).

Spearman's rho showed strong positive association between scavenging of wild birds on farms and presence of major rivers $(\mathrm{r}=1.00, \mathrm{p}=0.001)$; free range poultry and transit routes for live bird trade $(r=0.986, p=0.001)$; free range poultry and disposal of dead poultry in refuse dumps $(r=0.865, p=0.001)$; also spillage of feed and tress for roosting of wild birds on the farms $(\mathrm{r}=1.00, \mathrm{p}=$ 0.001). The rates of occurrence of risk factors of likely poultry and wild bird interactions were high in eight LGAs which included Olamaboro (83.7\%), Ajaokuta (76.8\%), Dekina and Ofu (each with 72.7\%), Ankpa and Lokoja (each with 68.6\%), Okene (64.5\%) and Ogori-Mangogo (61.7\%, Table 2).

The risk pathways for poultry and wild bird interactions with likely introduction of avian pathogens and the infection cycle involving the poultry value chain in the study area with considerations of the migration of wild birds are shown in Figure 1. The data obtained from this study showed that rural poultry constituted the major type of poultry production with more birds kept under extensive management system than under intensive management system (Figure 2).

Factors observed by the researchers that could promote poultry and wild bird interactions and spread of 
avian pathogens in the study area were mixing of different species of poultry and even captive wild birds in the LBMs; mixing of backyard commercial poultry with rural poultry and free flying wild birds; presence of large water bodies, major rivers and wetlands among others (Figures 3-6). Several free flying wild birds were seen around poultry farms and households during the study and were photographed for identification. The birds were identified with their local names, common names, families, and migratory status (Table 3 ).
Composite assessment of risk factors in the agro
zones
The risk factors of likely poultry and wild bird interactions were compared using univariate analysis across the three agro-zones. The occurrence of the risk factors for poultry and wild bird interactions in zone $\mathrm{C}$ was more than any of the other two zones but when the odds of occurrence were considered, there were not significant except for the presence of rivers or wetlands (Table 4).

Table 1. Grouping of the surveyed Local Government Areas based on the frequency of occurrence of risk factors that may favor poultry and wild bird interactions and spread of avian pathogens in Kogi State, Nigeria

\begin{tabular}{|c|c|c|c|}
\hline \multirow{2}{*}{ Risk factors } & \multicolumn{3}{|c|}{ Classification of LGAs based on the frequency of occurrence of risk factors } \\
\hline & Low risk & Medium risk & High risk \\
\hline \multicolumn{4}{|l|}{ Direct risk factors } \\
\hline Scavenging by wild birds & MPA & $\begin{array}{l}\text { DAV, DKA, JMU, KAB, } \\
\text { OGM, KPA }\end{array}$ & $\begin{array}{c}\text { AJA, LKJ, KFU, KNE, } \\
\text { LAM }\end{array}$ \\
\hline Free range poultry & & KNE, LAM & $\begin{array}{c}\text { OGM, DAV, AJA, KPA, } \\
\text { DKA, JMU, KAB, LKJ, } \\
\text { MPA, KFU }\end{array}$ \\
\hline $\begin{array}{l}\text { Improper disposal of carcass or } \\
\text { litter }\end{array}$ & OGM & $\begin{array}{l}\text { AJA, MPA, KNE, LAM, } \\
\text { JMU, KAB }\end{array}$ & $\begin{array}{c}\mathrm{LKJ}, \mathrm{KFU}, \mathrm{DAV}, \mathrm{KPA}, \\
\text { DKA }\end{array}$ \\
\hline $\begin{array}{l}\text { Spillage of feed, drying of feed } \\
\text { materials outside }\end{array}$ & KFU, LKJ & $\begin{array}{c}\text { JMU, KAB, MPA, OGM, } \\
\text { KNE, LAM }\end{array}$ & DAV, AJA, DKA, KPA \\
\hline $\begin{array}{l}\text { Fish pond or surface water on } \\
\text { poultry farm/household }\end{array}$ & LAM, KFU, OGM, KPA & $\begin{array}{c}\text { DAV, AJA, JMU, DKA, } \\
\text { KAB, KNE }\end{array}$ & MPA, LKJ \\
\hline
\end{tabular}

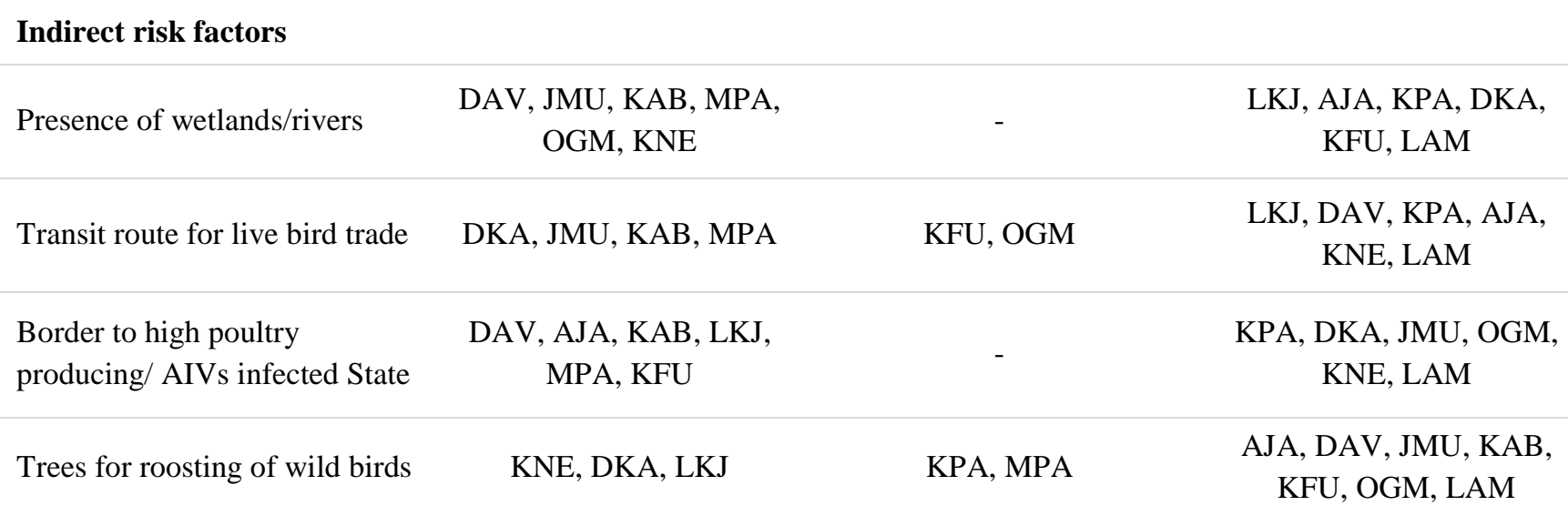

AIVs: Avian influenza viruses, LGAs: local government areas, DAV: Adavi, KPA: Ankpa, AJA: Ajaokuta, DKA: Dekina, JMU: Ijumu, KAB: Kabba/Bunu, LKJ: Lokoja, MPA: Mopamuro, KFU: Ofu, OGM: Ogori-Mangogo, KNE: Okene, LAM: Olamaboro). 
Table 2. Rates of occurrence of risk factors associated with poultry and wild bird interactions and spread of avian pathogens in the surveyed Local Government Areas of Kogi State, Nigeria

\begin{tabular}{|c|c|c|c|c|c|c|c|c|c|c|c|c|c|}
\hline Risk factor & $\begin{array}{c}\text { DAV } \\
\mathrm{n}=9 \\
\%\end{array}$ & $\begin{array}{c}\text { AJA } \\
\mathrm{n}=9 \\
\%\end{array}$ & $\begin{array}{c}\mathrm{KPA} \\
\mathrm{n}=9 \\
\%\end{array}$ & $\begin{array}{c}\text { DKA } \\
\mathrm{n}=9 \\
\%\end{array}$ & $\begin{array}{c}\text { JMU } \\
\mathrm{n}=9 \\
\%\end{array}$ & $\begin{array}{c}\text { KAB } \\
n=9 \\
\%\end{array}$ & $\begin{array}{c}\text { LKJ } \\
\mathrm{n}=9 \\
\%\end{array}$ & $\begin{array}{c}\text { MPA } \\
\%\end{array}$ & $\begin{array}{c}\mathrm{KFU} \\
\mathrm{n}=9 \\
\%\end{array}$ & $\begin{array}{c}\text { OGM } \\
\mathrm{n}=9 \\
\%\end{array}$ & $\begin{array}{c}\text { KNE } \\
\mathrm{n}=9 \\
\%\end{array}$ & $\begin{array}{c}\text { LAM } \\
\mathrm{n}=9 \\
\%\end{array}$ & $\begin{array}{c}\text { Total } \\
\mathrm{N}=108 \\
\%\end{array}$ \\
\hline \multicolumn{14}{|l|}{ Direct risk factors } \\
\hline Scavenging by wild birds & 66.7 & 100 & 55.6 & 66.7 & 66.7 & 66.7 & 100 & 44.4 & 100 & 66.7 & 100 & 100 & 86.4 \\
\hline Free range poultry & 66.7 & 66.7 & 66.7 & 66.7 & 66.7 & 66.7 & 66.7 & 66.7 & 66.7 & 77.8 & 55.6 & 55.6 & 73.1 \\
\hline Improper disposal of carcass or litter & 100 & 100 & 100 & 100 & 88.9 & 88.9 & 66.7 & 77.8 & 66.7 & 77.8 & 77.8 & 77.8 & 94.7 \\
\hline Spillage of feed, drying of feed materials outside & 55.6 & 44.4 & 77.8 & 88.9 & 33.3 & 33.3 & 55.6 & 44.4 & 66.7 & 22.2 & 44.4 & 44.4 & 53.5 \\
\hline Fish pond or surface water on poultry farm/household & 11.1 & 11.1 & 0.0 & 11.1 & 11.1 & 11.1 & 11.1 & 22.2 & 0 & 0 & 11.1 & 0.0 & 9.3 \\
\hline \multicolumn{14}{|l|}{ Indirect risk factors } \\
\hline Presence of wetlands/rivers & 0.0 & 100 & 100 & 100 & 0.0 & 0.0 & 100 & 0 & 100 & 0 & 0.0 & 100 & 55.6 \\
\hline Transit route for live bird trade & 100 & 100 & 100 & 22.2 & 11.1 & 11.1 & 100 & 11.1 & 88.9 & 88.9 & 100 & 100 & 77.2 \\
\hline Border to poultry producing/ AIVs infected State & 0.0 & 0,0 & 100 & 100 & 100 & 0.0 & 0.0 & 0.0 & 0.0 & 100 & 100 & 100 & 55.6 \\
\hline Trees for roosting of wild birds & 77.8 & 100 & 55.6 & 33.3 & 66.7 & 66.7 & 55.6 & 44.4 & 100 & 66.7 & 33.3 & 100 & 67.9 \\
\hline Total, $\mathbf{N}=81$ & 59.0 & 76.8 & 68.6 & 72.7 & 54.9 & 42.5 & 68.6 & 38.4 & 72.7 & 61.7 & 64.5 & 83.7 & \\
\hline
\end{tabular}

$\mathrm{N}$ : Number of respondents in each LGA, \%: Rates of occurrence of risk factors, $\mathbf{N}$ : Total rates of risk factors in each LGA. 


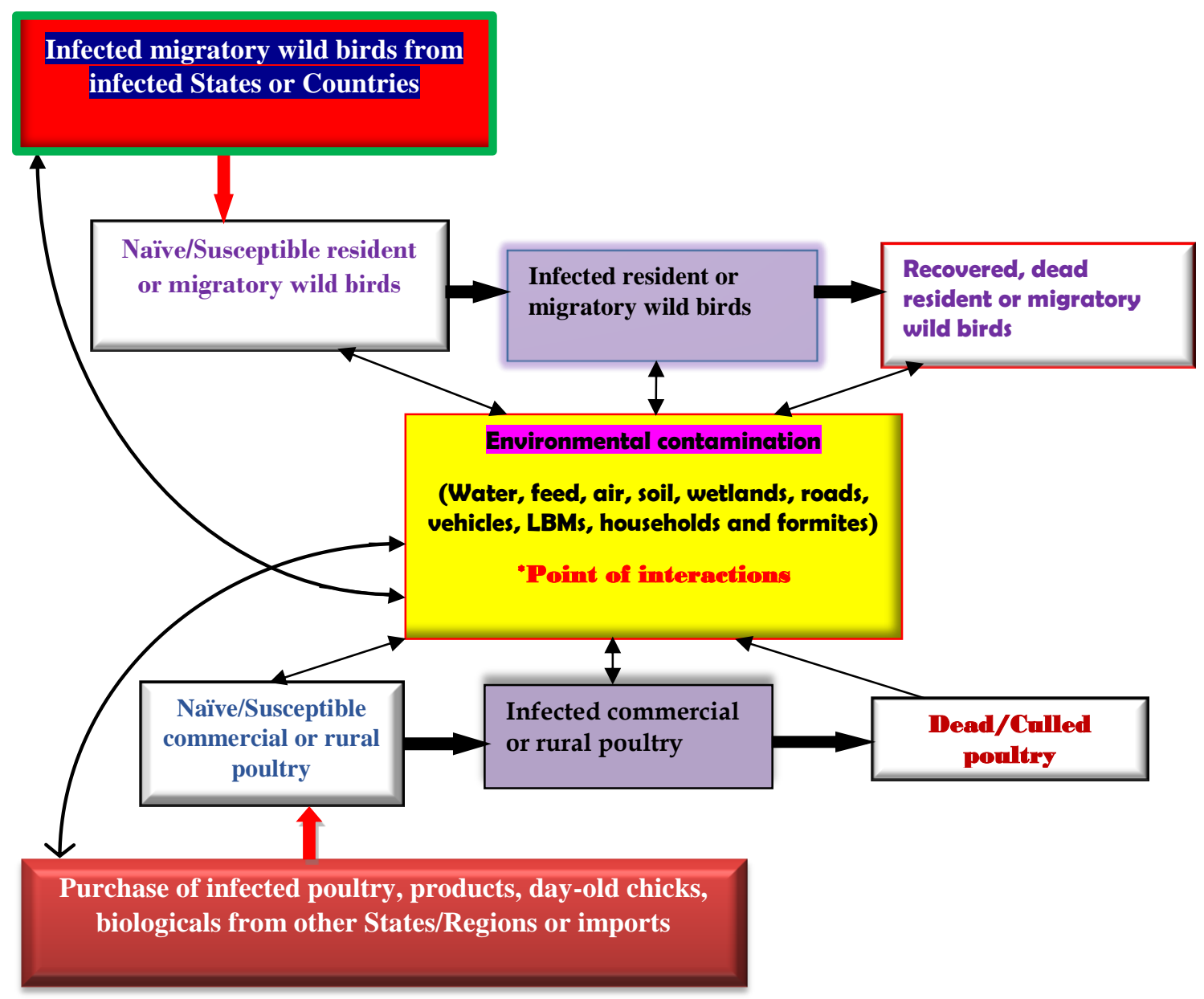

Figure 1. The risk pathways for poultry and wild bird interactions with likely introduction and spread of avian pathogens and the infection cycle in Kogi State, Nigeria. Red solid arrows indicate likely external sources of introduction of avian pathogens, black solid arrows indicate spread and progression of infections, single-headed black tiny arrows indicate direction of infections while double-headed arrows indicate possibility of cross infections

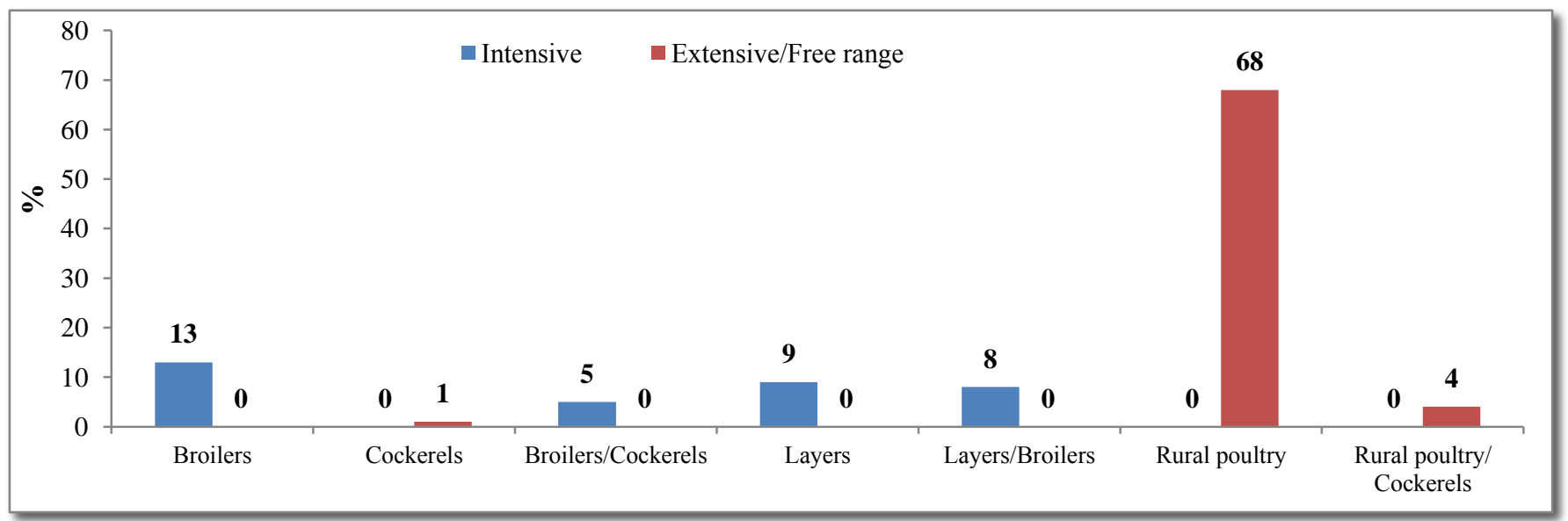

Figure 2. Types of poultry and management systems of production used by poultry farmers in this study 
Table 3. Wild birds frequently seen around households, poultry farms, and wetlands with their native names in Igala, Ebira, and Okun, the three major languages spoken by the people of Kogi State, Nigeria

\begin{tabular}{|c|c|c|c|c|c|}
\hline Common name & Family name & $\begin{array}{l}\text { Native name } \\
\text { (Igala) }\end{array}$ & $\begin{array}{l}\text { Native name } \\
\text { (Ebira) }\end{array}$ & $\begin{array}{l}\text { Native name } \\
\text { (Okun) }\end{array}$ & Migratory status \\
\hline Black stork & Ciconidae & Ẹwẹ-omi & Inomi - enyi & Ẹyẹ-omi & Migratory \\
\hline Vulture & Accipitridae & Ugwunu & Uba & Egunyẹyẹ & Migratory \\
\hline Swallow & Hirundinidae & Akpadede & Epandede & Apandede & Migratory/resident \\
\hline Swift & Apodidae & Aja & Irepe & Asa & Migratory/resident \\
\hline Dove & Columbidae & Ikede & Arivadi & Arubadi & Resident \\
\hline Cattle egret & Ardeidae & Ichakolo & Ane & Amioro & Migratory/resident \\
\hline Buzard & Accipitridae & Uji-omaga & Obono & Gangan & Migratory \\
\hline Pigeon & Columbidae & Oketebe & Arekuku & Ẹiyẹle & Resident \\
\hline Black Kite & Accipitridae & Ugbono & Irepe/Ikokoro & No equivalence & Migratory \\
\hline Hawk & Accipitridae & Ukokolo & Ukokoro & No equivalence & Migratory \\
\hline Owl & Strigidae & Ogugu-nokwu & Igugu & No equivalence & Migratory/resident \\
\hline Cuckoos & Cuculidae & Obututu & No equivalence & No equivalence & Resident \\
\hline
\end{tabular}

Table 4. Univariate analysis of risk factors for possible poultry and wild bird interactions and spread of avian pathogens in Kogi State, Nigeria

\begin{tabular}{|c|c|c|c|c|}
\hline Variable factor & $\begin{array}{c}\mathbf{A}+\mathbf{B} \\
\mathbf{n}=72(\%)\end{array}$ & $\begin{array}{c}\mathrm{C} \\
\mathrm{n}=\mathbf{3 6}(\%)\end{array}$ & OR $(95 \% \mathrm{CI})$ & p-value \\
\hline Disposal of litter in refuse dump & $61(84.7)$ & $31(86.1)$ & $1.123(0.362-3.501)$ & 0.848 \\
\hline Scavenging of wild birds on farms & $55(76.4)$ & $29(80.6)$ & $1.281(0.477-3.441)$ & 0.623 \\
\hline Poultry on free range & $48(66.7)$ & $24(66.7$ & $1.00(0.428-2.337)$ & 1.00 \\
\hline Wild bird roosting on trees around farms andlive bird markets & $46(63.9)$ & $26(72.2)$ & $1.470(0.613-3.520)$ & 0.386 \\
\hline $\begin{array}{l}\text { Spillage of feed on farms andlive bird marketsor drying of } \\
\text { ingredients in the open }\end{array}$ & $24(33.3)$ & $10(27.8)$ & $0.769(0.320-1.852)$ & 0.558 \\
\hline Water body or open fish pond & $8(11.1)$ & $1(2.8)$ & $0.229(0.027-1.903)$ & 0.140 \\
\hline Presence of rivers or wetlands & $18(25.0)$ & $30(83.3)$ & $\begin{array}{c}15.00(5.376- \\
41.852)\end{array}$ & $0.002 *$ \\
\hline
\end{tabular}




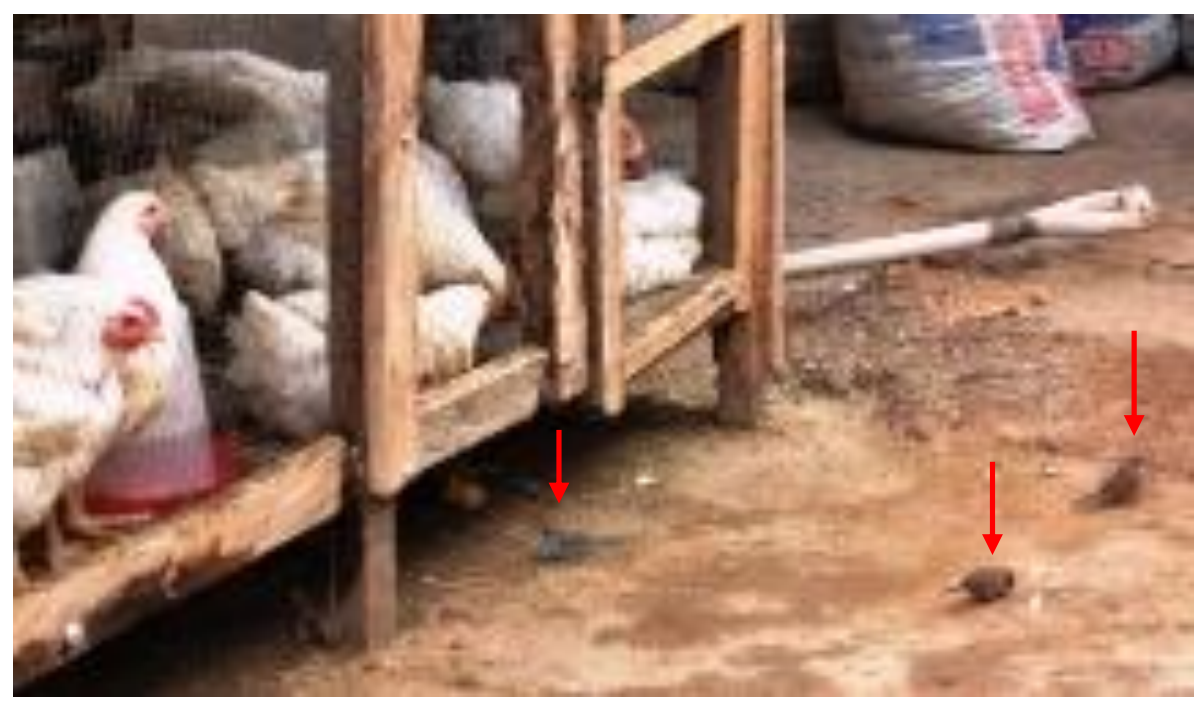

Figure 3. Broilers reared in a wooden cage with wild birds (red arrows) scavenging on spillage feed in a backyard poultry farm located in Kabba in Kabba/Bunu local government area, Kogi State, Nigeria

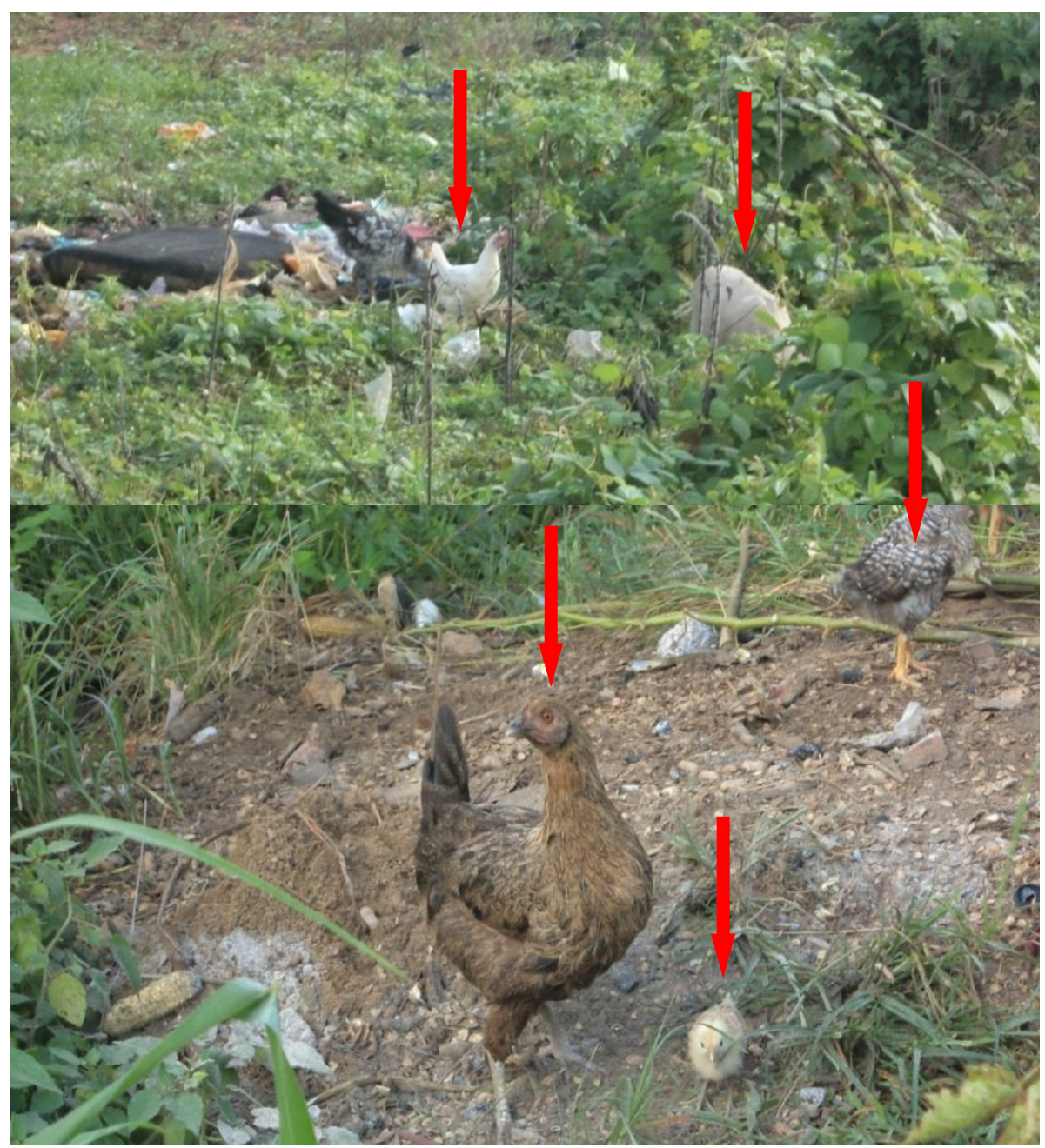

Figure 4. Rural poultry (red arrows) on free range with other animals scavenging in refuse dumpsites in a rural community in Olamaboro local government area, Kogi State, Nigeria 


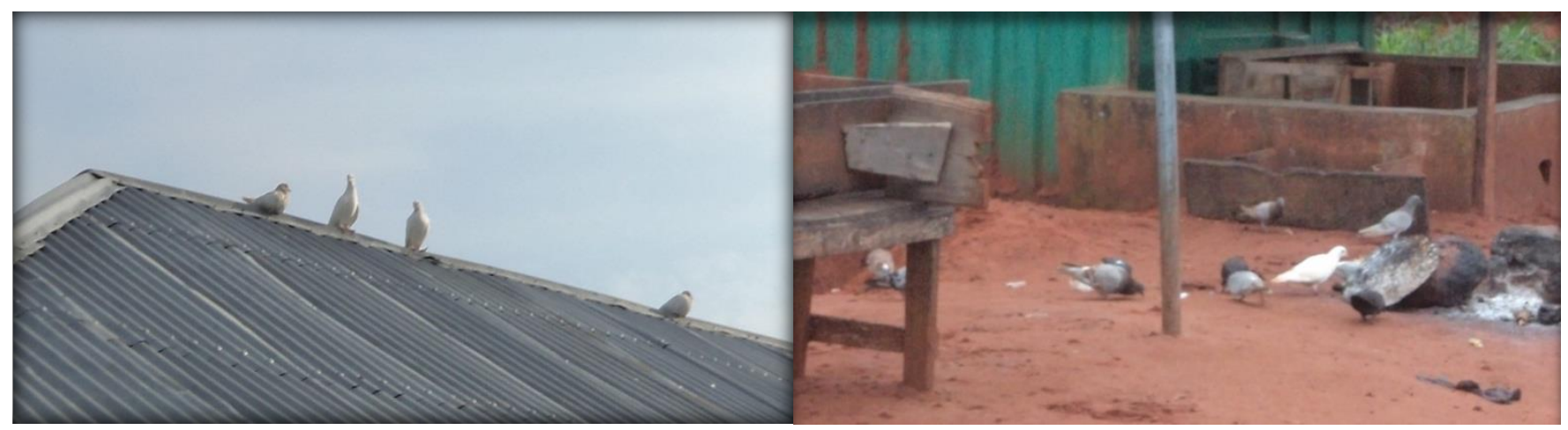

Figure 5. Domesticated and free flying wild pigeons flocking together around a household in Okenwe in Okene local government area, Kogi State

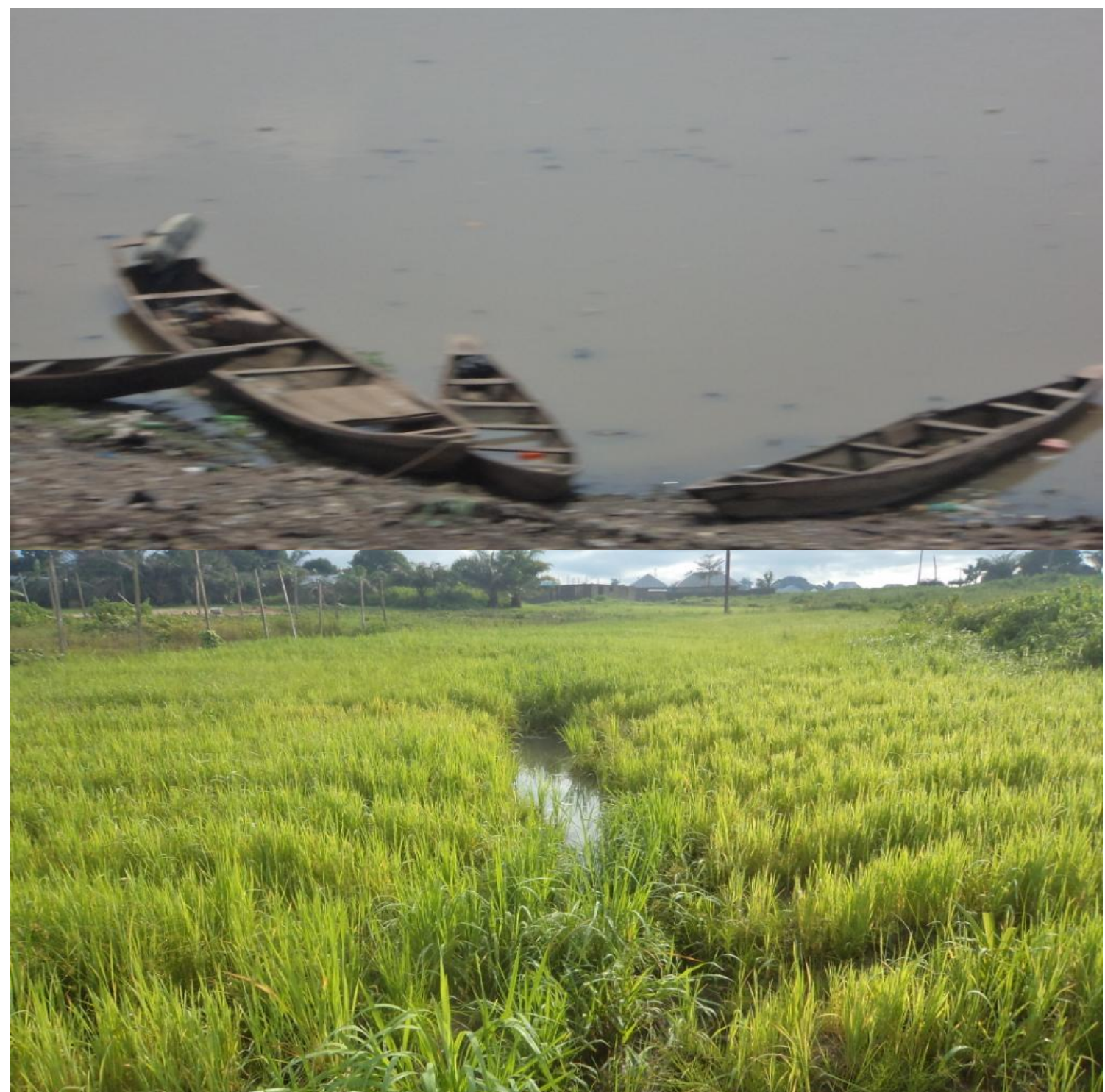

Figure 6. The convergence of two major rivers, Benue and Niger at Lokoja to form a confluence (A). Marshy wetland used for rice farming in Ajaokuta local government area (B), Kogi State, Nigeria 


\section{DISCUSSION}

Most of the LGAs surveyed, especially those with wetlands or major rivers, disposal of litter or dead poultry in refuse dump sites and free ranging poultry such as Ajaokuta, Dekina, Olamaboro, Ofu, Ankpa, Lokoja, Okene, and Ogori-Mangogo were found to be at high risk of poultry and wild bird interactions. This poses a great risk for the spread of contagious avian diseases or pathogens which may hinder commercial poultry production in the State as reported in this study. However, this finding is in conformity with the report of $\mathrm{Si}$ et al. (2013) who found that the distribution of human population and high poultry production in addition to proximity to rivers or wetlands were factors that influenced interactive pathways between poultry and wild birds. The study area though, a State within the hinterland, lies within the Niger-Benue confluence, lower Niger/Anambra river flood plain, and lower Benue flood plain that are frequented by resident and migratory birds (Abdu, 2010). Consequent upon this, poultry farmers in the State need to shift from the traditional or extensive management system of poultry farming and embrace intensive poultry production in order to avoid the associated risk factors that can contribute to pathogens introduction and spread.

Boyce et al. (2009) also stated that wetlands had high prevalence of avian influenza viruses and transmission of other avian pathogens due to favorable biotic and abiotic factors such as the high density of naïve hosts, cool and wet environment that could enhance pathogens survival for fecal-oral transmission. Many avian pathogens, especially HPAI H5N1 are reported to survive in water or feces for long periods at low temperatures and remain infective in water for up to 207 days at $17^{\circ} \mathrm{C}$ and up to 102 days at $28^{\circ} \mathrm{C}$ as well as in liquid feces for up to 35 days at $4^{\circ} \mathrm{C}$ or 7 days at $20^{\circ} \mathrm{C}$ (Stallknecht et al., 1990). The long environmental survival of some avian pathogens in water and in other biological carriers makes their dispersal over wide areas and long distances possible once discharged by wild birds or any infected avian species, a possible scenario that can occur in the study area due to the presence of major rivers and wetlands.

The indication of high level of scavenging by wild birds on poultry farms and poultry on free range in most LGAs as observed in this study coupled with the indiscriminate disposal of poultry litter and dead birds in refuse dumps might create a platform for direct or indirect contacts and mutual sharing of many infectious pathogens between wild birds and domestic poultry.

The scavenging of wild birds on poultry farms, households, and around LBMs, the spillage of feed during feeding of poultry or drying of feed ingredients on poultry farms and households bring wild birds directly into close contact with poultry for possible interactions in competing for food, water, and space. Rural poultry on free range as well as the extensive management system of backyard commercial poultry also bring poultry and wild birds directly into close activity space which may lead to the introduction and spread of avian pathogens with a concomitant increase in cost of disease control and decline in productivity.

Most of the wild birds seen around poultry farms and households which were commonly known to the local people such as stork, hawk, swift, swallow, and egret are migratory species in which important avian pathogens have been detected (FAO 2007, Ameji et al, 2015). This underscores the inherent danger in the interactions between wild birds and poultry in the area with subsequent effects on poultry production.

Different species and multiage birds are often held together in the LBMs until they are sold out which may lead to the sharing of pathogens. Ameji et al. (2012) reported that some farmers sourced poultry rearing stock from the LBMs, a practice that can cause disease outbreaks in a naïve and susceptible flock if the new one has a latent infection.

There is a need to educate poultry farmers and sellers in Kogi State, Nigeria on the appropriate husbandry and biosecurity practices to adopt to reduce poultry and wild bird interactions in order to prevent the introduction and spread of avian pathogens by wild birds.

\section{DECLARATIONS}

\section{Competing interests}

The authors declare that there is no conflict of interest

\section{Acknowledgments}

The authors wish to acknowledge the immense assistance of the Kogi State Avian Influenza Area Desk Officers and National Animal Disease Information System agents in the twelve LGAs visited for the study.

\section{Authors' contributions}

Ameji Negedu Onogu designed the project, collected and analyzed data, wrote the draft of the manuscript, Assam Assam participated in data collection, analysis of 
data, and review of manuscript, Abdu Paul Ayuba participated in design, supervision, and review of manuscript, Sa'idu Lawal participated in design, supervision, and review while Murtala Isa-Ochepa participated in data collection and report writing.

\section{REFERENCES}

Abdu PA (2010). Qualitative risk assessment on the transmission of HPAI (H5N1) virus from backyard and medium-scale commercial farms to household free-range poultry in Nigeria. Africa/Indonesia Team Working Paper, pp.1 - 103, 29 October 2010. Available at: https://www.hpairesearch.net

Adene DF and Oguntade AE (2006). The structure and importance of the commercial and rural based poultry industry in Nigeria. FAO (Rome) study, pp.1-70, October 2006. Available

at: www.fao.org/avianflu/en/farmingsystems.html

Ameji NO, Abdu PA and Sa'idu L (2015). Newcastle disease antibodies in apparently healthy wild birds in Kogi state, Nigeria. Research Journal of Veterinary Sciences, 8 (3): 5260. DOI: https://www.doi.org/10.3923/rjvs.2015.52.60

Ameji NO, Abdu PA, Sa'idu L and Isa - Ochepa M (2012). Knowledge of poultry diseases, biosecurity and husbandry practices among stakeholders in poultry production in Kogi State, Nigeria. Sokoto Journal of Veterinary Sciences, 10(2): 26-31. DOI: http://dx.doi.org/10.4314/sokjvs.v10i2.6

Borrow N and Demey R (2002). Birds of Western Africa: An identification guide. Helm identification guide series, Helm, Publishers, pp.1-832.

Boyce WM, Sandrock C, Kreuder-Johnson C, Kelly T and Cardona C (2009). Avian influenza viruses in wild birds: a moving target. Comparative Immunology and Microbiology of Infectious Diseases, 32: $275-286 . \quad$ DOI: https://www.doi:org/10.1016/j.cimid.2008.01.002

Dhama K, Mahendran M and Tomar S (2008). Pathogens transmitted by migratory birds: Threat perceptions to poultry health and production. International Journal of Poultry Science, 7 (6): 516 - 525. DOI: https://www.doi.org/10.3923/ijps.2008.516.525

Elmberg J, Berg C, Lerner $\mathrm{H}$, Waldenström $\mathrm{J}$ and Hessel $\mathrm{R}$ (2017). Potential disease transmission from wild geese and swans to livestock, poultry and humans: a review of the scientific literature from a One Health perspective. Infection Ecology and Epidemiology, 7: 1-22. DOI: https://www.doi.org/10.1080/20008686.2017.1300450

Food and Agricultural Organization (FAO) (2007). Wild birds and avian influenza: An introduction to applied field research and disease sampling techniques. Whitworth $\mathrm{D}$, Newman SH, Mundkur T and Harris P. (Eds). FAO Animal Production and Health Manual, No. 5, Rome. Available at: https://www.fao.org/avianflu

Gilbert M, Xiao X. Pfeiffer DU, Epprecht M, Boles S, Czarnecki C, Chaitaweesub P, Kalpravidh W, Minh PQ, Otte MJ, Martin V and Slingenbergh J (2008). Mapping H5N1 highly pathogenic avian influenza risk in Southeast Asia.
Proceedings of the National Academy of Sciences, USA, 105: 4769-4774. DOI: https://www.doi.org/10.1073/pnas.0710581105

Halifa M (2008). Strategies for the prevention and control of infectious diseases (including highly pathogenic avian influenza) in Eastern Africa: Good biosecurity practices in non-integrated commercial and in scavenging production systems in Tanzania. FAO Study report, pp. 1-28.

Hernandez-Jover M, Schemann K, East IJ and Toribio JA (2015). Evaluating the risk of avian influenza introduction and spread among poultry exhibition flocks in Australia. Preventive Veterinary Medicine, 118 (1): 128 - 141. DOI: https://www.doi.org/10.1016/j.prevetmed.2014.11.018

Kilpatrick AM, Chmura AA, Gibbons DW, Fleischer RC and Marra PP (2006). Predicting the global spread of H5N1 avian influenza. Proceedings of National Academy Science, 103 (51): 19368-19373. https://www.doi.org/10.1073/pnas.0609227103

Kogi, (2009). Kogi State Agricultural Development Projects. In: Encyclopaedia Britannica, Available at: http://www.britannica.com/kogistate/agric/index.html.

Lee DH, Bertran K, Kwon JH and Swayne DE (2017). Evolution, global spread and pathogenicity of highly pathogenic avian influenza $\mathrm{H} 5 \mathrm{Nx}$ clade 2.3.4.4. Journal of Veterinary Science, $\quad 18(\mathrm{~S} 1)$ : $\quad 269-280 . \quad$ DOI: https://www.doi.org/10.4142/jvs.2017.18.S1.269

Pagani P, Abimiku YJE and Emeka-Okolie W (2008). Assessment of the Nigerian poultry market chain to improve biosecurity. FAO (Nigeria, Consultative Mission on Poultry) Study, pp. 1 - 65, November 2008. Available at: https://www.fao.org/a-ak778e.pdf

Si Y, de Boer WF and Gong P (2013). Different environmental drivers of highly pathogenic avian influenza H5N1 outbreaks in poultry and wild birds. PLoS ONE, 8(1): e53362.

DOI: https://www.doi.org/10.1371/journal.pone.0053362

Singh M, Toribio J-A, Scott AB, Groves P, Barnes B, Glass K, Maloney B, Black A and Hernandez-Jover M (2018). Assessing the probability of introduction and spread of avian influenza (AI) virus in commercial Australian poultry operations using an expert opinion elicitation. PLoS ONE, 13(3): e0193730. DOI: https://www.doi.org/10.1371/journal.pone.0193730

Snedecor GW and Cochran WG (1989). Statistical Methods $\left(8^{\text {th }}\right.$ Ed.). Ames: Iowa State University Press, pp. 45-56.

Stallknecht DE, Shane SM, Kearney MT and Zwank BPJ (1990). Persistence of avian influenza viruses in water. Avian Diseases, 34: 406-411.

United State Agency for International Development (USAID)/ Stop AI (2009). Biosecurity for farms and markets in Nigeria. USAID Trainer guide, Kaduna, Nigeria, January 12-23, 2009.

Vieira AR, Hofacre CL, Smith JA and Cole D (2009). Human contacts and potential pathways of disease introduction on Georgia poultry farms. Avian diseases, 53(1):55-62. DOI: https://www.doi.org/10.1637/8364-051608-Reg.1 PMID: 19432004 